\title{
Efektifitas Pemberian Kompres Tepid Water Sponge dan Pemberian Kompres Bawang Merah Terhadap Penurunan Suhu Tubuh Anak Demam di Banjarmasin, Kalimantan Selatan
}

\author{
Ibnu Rifaldi ${ }^{1}$, Dewi Kartika Wulandari \\ ${ }^{1}$ Mahasiswa Universitas Muhammadiyah Banjarmasin \\ ${ }^{2}$ Dosen Universitas Muhammadiyah Banjarmasin \\ Email: adekadilan@gmail.com
}

\begin{abstract}
Child health problems are one of the main problems in the health sector which is currently a priority in Indonesia. One of the symptoms that often occurs in children is fever. An increase in body temperature often occurs in children because their immune system is still weak, susceptible to exposure to bacteria or viruses, so they are prone to fever. Fever can endanger the safety of children if not treated quickly and appropriately, and can lead to other complications such as hyperthermia, seizures and decreased consciousness. This study aims to compare the provision of interventions to reduce fever in children, namely the Tepid Water Sponge and the Red Onion Compress. This study used the Paired T-Test with the design of Two group Pre-Post-test with a sample of 32 people. The results showed that there was a difference in the effectiveness of the tepid water sponge compress and the onion compress. The compress of tepid water sponge has a mean value after treatment of $36.65^{\circ} \mathrm{C}$ while compress of onion has a mean value of $37.15^{\circ} \mathrm{C}$ after treatment. The conclusion of this study is that the application of the Tepid Water Sponge compress is more effective at lowering body temperature than compressing the onion. It is recommended that parents apply Tepid Water Sponge compresses to feverish children before heading to further health services.
\end{abstract}

Keywords: Fever, Onion compress, Tepid Water Sponge, Body Temperature.

\begin{abstract}
Abstrak
Masalah kesehatan anak merupakan salah satu masalah utama dalam bidang kesehatan yang saat ini menjadi prioritas di Indonesia. Salah satu gejala yang sering sekali terjadi pada anak adalah demam. Peningkatan suhu tubuh banyak terjadi pada anak karena sistem pertahanan tubuhnya masih lemah, rentan terpapar bakteri atau virus sehingga mudah terkena demam. Demam dapat membahayakan keselamatan anak jika tidak ditangani dengan cepat dan tepat, serta dapat menimbulkan komplikasi lain seperti, hipertermi, kejang dan penurunan kesadaran. Penelitian ini bertujuan untuk melihat perbandingan pemberian intervensi untuk mengurangi demam pada anak, yaitu dengan Tepif Water Sponge dan Kompres Bawang Merah. Penelitian ini menggunakan uji Paired T-Test dengan rancangan Two group Pre test-Post test dengan sampel sebanyak 32 orang. Hasil penelitian menunjukkan ada perbedaan efektifitas antara kompres tepid water sponge dengan kompres bawang merah. Kompres tepid water sponge bernilai mean sesudah perlakuan $36,65^{\circ} \mathrm{C}$ sedangkan kompres bawang merah bernilai mean sesudah perlakuan $37,15^{\circ} \mathrm{C}$. Kesimpulan dari penelitian ini adalah pemberian kompres Tepid Water Sponge ternyata lebih efektif untuk menurunkan suhu tubuh dibandingkan dengan kompres bawang merah. Disarankan kepada orang tua untuk melakukan kompres Tepid Water Sponge terhadap anak demam sebelum menuju ke pelayanan kesehatan lebih lanjut.
\end{abstract}

Kata kunci: Demam, Kompres Bawang Merah, Kompres Tepid Water Sponge, Suhu Tubuh.

\section{Pendahuluan}

Masalah kesehatan anak merupakan salah satu masalah utama dalam bidang kesehatan yang saat ini terjadi di Indonesia. Salah satu gejala yang rentan dan sering sekali terjadi pada anak adalah demam. Demam memang bukan merupakan suatu penyakit, Biasanya gejala demam terjadi karena adanya kemungkinan masuknya suatu bibit penyakit dalam tubuh. Secara alami, suhu tubuh mempertahankan diri dari serangan suatu penyakit dengan meningkatkan suhu tubuh (Hidayat, 2015).

Badan Kesehatan Dunia (WHO) memperkirakan jumlah kasus demam di seluruh Dunia mencapai 16 - 33 juta dengan 500 - 600 ribu kematian tiap tahunnya yang disebabkan karena komplikasi dari demam, seperti: hipertermi, kejang dan penurunan 
kesadaran. Insiden penderita demam di Indonesia sebanyak $465(91.0 \%)$ dari 511 ibu yang memakai perabaan untuk menilai demam pada anak mereka sedangkan sisanya $23,1 \%$ saja menggunakan termometer (Wardiyah et al, 2016).

Kalimantan Selatan merupakan daerah tropis sehingga banyak kasus penyakit infeksi yang manifestasinya berupa demam. Berdasarkan fenomena yang terjadi komplikasi kejang kemungkinan akan terjadi jika tidak ditangani dengan cepat. Dari laporan Dinas Kesehatan Provinsi Banjarmasin tercatat bahwa 3.902 orang mengalami penyakit demam berdarah (DBD) yang dapat menyebabkan kematian (Dinkes, 2018). Puskesmas Basirih Baru Banjarmasin merupakan salah satu puskesmas yang ada di Banjarmasin dan masuk ke urutan 9 besar dengan kasus anak terbanyak. Menurut data yang didapatkan dari Puskesmas Basirih Banjarmasin angka kejadian demam pada bulan Januari - Mei 2019 terjadi sebanyak 426 anak yang terkena gejala demam, kasus Febris (237), Demam Typoid (69), DBD (32), Tonsilitis (88). Angka kejadian demam tersebut masih termasuk tinggi seiring dengan masih banyaknya angka kejadian penyakit tropis.

Selama proses pertumbuhan dan perkembangan, anak sering mengalami sakit. Terlebih lagi pada anak usia prasekolah (Usia 3-6 Tahun ) dimana sistem imun anak masih lemah, dan dimana pada usia anak prasekolah lebih aktif dalam melakukan banyak hal yang membuat tubuh anak rentan terserang yang dapat membuat anak mengalami demam (Dewi, 2016). Demam pada anak dibutuhkan perlakuan dan penanganan tersendiri yang berbeda bila dibandingkan dengan orang dewasa. Hal ini dikarenakan, apabila tindakan dalam mengatasi demam tidak tepat dan lambat maka akan mengakibatkan pertumbuhan dan perkembangan anak terganggu. Demam dapat membahayakan keselamatan anak jika tidak ditangani dengan cepat dan tepat, serta dapat menimbulkan komplikasi lain seperti, hipertermi, kejang dan penurunan kesadaran. (Wardiyah et $a$, 2016).

Menurunkan atau mengendalikan dan mengontrol demam pada anak dapat dilakukan dengan berbagai cara, diantaranya dapat dilakukan dengan pemberian antipiretik (farmakologik), selain penggunaan obat antipiretik, penurunan suhu tubuh dapat dilakukan secara fisik (non farmakologik) dan penggunaan obat tradisional, yaitu dengan penggunaan energi panas melalui metode konduksi dan evaporasi. Metode konduksi yaitu perpindahan panas dari suatu objek lain dengan kontak langsung. Ketika kulit hangat menyentuh yang hangat maka akan terjadi perpindahan panas melalui evaporasi, sehingga perpindahan energi panas berubah menjadi gas. Contoh dari metode konduksi dan evaporasi adalah penggunaan kompres dan juga dapat dilakukan dengan obat tradisional (Yohana dan Andriani, 2012).
Kompres adalah salah satu metode fisik untuk menurunkan suhu tubuh bila mengalami demam, prinsip tepid water sponge dapat menurunkan suhu tubuh melalui proses penguapan sehingga dapat memperlancar sirkulasi darah kemudian darah akan mengalir dari organ dalam ke permukaan tubuh dengan membawa panas. Kulit memiliki banyak pembuluh darah, terutama tangan, kaki, dan telinga. Aliran darah melalui kulit dapat mencapai 30\% dari darah yang dipompakan jantung, kemudian panas berpindah dari darah melalui kulit dan hilang ke lingkungan sehingga terjadi penurunan suhu tubuh. (Potter \& Perry, 2010 dalam Wardiyah et al, 2016). Terapi non farmakologi untuk demam yang lain yaitu penggunaan obat tradisional. Obat tradisional adalah obat yang diolah secara tradisional dan diajarkan secara turun temurun berdasarkan resep nenek moyang, adat istiadat, kepercayaan atau kebiasaan setempat. Dari hasil berbagai penelitian, obat tradisional terbukti memiliki efek samping yang minim bahkan tanpa menimbulkan efek samping, karena bahan kimia yang terkandung dalam tanaman obat tradisional sebagian besar dapat di metabolisme oleh tubuh (Tusilawati, 2012).

Salah satu tanaman obat yang dapat digunakan untuk mengendalikan demam adalah bawang merah (Allium Cepa varascalonicum). Bawang merah mengandung senyawa sulfur organic yaitu Allylcysteine sulfoxide (Alliin). Bawang merah yang digerus akan melepaskan enzim alliinase yang berfungsi sebagai katalisator untuk alliin yang akan bereaksi dengan senyawa lain misalnya kulit yang berfungsi menghancurkan bekuan darah. Kandungan minyak atsiri dalam bawang merah juga dapat melancarkan peredaran darah sehingga peredaran darah menjadi lancar. Kandungan lain dari bawang merah yang dapat menurunkan suhu tubuh adalah florogusin, sikloaliin, metialin, dan kaemferol (Tusilawati, 2012).

Mekanisme penurunan suhu tubuh saat diberikan kompres bawang merah yang disapukan di seluruh badan anak akan membuat pembuluh darah vena berubah ukuran yang diatur oleh hipotalamus anterior untuk mengontrol pengeluaran panas, sehingga terjadi vasodilatasi (pelebaran) pembuluh darah dan hambatan produksi panas. Darah didistribusi kembali ke pembuluh darah permukaan untuk meningkatkan pengeluaran panas. Terjadinya vasodilatasi ini menyebabkan pembuangan panas melalui kulit meningkat, pori-pori membesar, dan mempercepat pengeluaran panas secara evaporasi (berkeringat) dibandingkan hanya mengompres di salah satu bagian tubuh saja seperti pada bagian lipatan (aksila) dan diharapkan akan terjadi penurunan suhu tubuh mencapai keadaan normal kembali (Potter \& Perry, 2010 dalam Wardiyah et al, 2016). Penelitian ini menganalisis efektifitas pemberian kompres tepid water sponge dan pemberian kompres bawang merah terhadap penurunan suhu tubuh anak demam. 


\section{Metode Penelitian}

Desain penelitian yang digunakan dalam penelitian ini adalah Pra-eksperimen dengan rancangan Two group Pretest-Postest dengan populasi dalam rancangan ini dibagi dari 2 kelompok yakni kelompok kompres tepid water sponge dan kelompok kompres bawang merah (Notoadmojo, 2010). Populasi pada penelitian ini adalah anakanak demam laki-laki/perempuan yang ada di wilayah kerja puskesmas Basirih Baru yang berjumlah 426 orang berdasarkan data dari bulan Januari - Mei 2019. Pengambilan sampel dalam penelitian ini dengan menggunakan rumus experimental dan didapatkan sampel sebanyak 32 responden yang dibagi menjadi 2 kelompok penelitian yaitu 16 orang diberikan intervensi kompres tepid water sponge dan 16 orang lainnya diberikan intervensi kompres bawang merah. Kriteria pengambilan sampel adalah 1) Anak yang diukur suhu tubuh aksila menggunakan termometer digital menunjukkan angka $>37,2{ }^{\circ} \mathrm{C}$. 2) Anak usia prasekolah rentang 3 - 6 tahun dan di dampingi orang tuanya menjadi responden. 3) Anak yang belum mengonsumsi obat antipiretik atau telah mengonsumsi obat setelah 4 jam reaksi obat.

\section{Hasil Penelitian}

A. Karakteristik Responden Hasil penelitian ini berdasarkan karakteristik umur, jenis kelamin dan penyakit yang diderita.

Tabel 1.1 Karakteristik Responden Berdasarkan Umur, jenis kelamin dan penyakit yang diderita.

\begin{tabular}{|c|c|c|c|c|}
\hline \multirow{2}{*}{$\begin{array}{l}\text { No } \\
1\end{array}$} & \multicolumn{2}{|c|}{ Karakteristik } & \multirow{2}{*}{$\begin{array}{c}\text { Frekuensi } \\
6\end{array}$} & \multirow{2}{*}{$\begin{array}{c}\% \\
18,75 \% \\
\end{array}$} \\
\hline & Usia & 3 Tahun & & \\
\hline 2 & & 3,5 Tahun & 2 & $6,25 \%$ \\
\hline 3 & & 4,2 Tahun & 1 & $3,12 \%$ \\
\hline 4 & & 4 Tahun & 7 & $21,87 \%$ \\
\hline 5 & & 4,4 Tahun & 2 & $6,25 \%$ \\
\hline 6 & & 5 Tahun & 6 & $18,75 \%$ \\
\hline \multirow[t]{2}{*}{7} & & 6 Tahun & 8 & $25 \%$ \\
\hline & \multicolumn{2}{|c|}{ Total } & 32 & $100 \%$ \\
\hline 1 & \multirow[t]{2}{*}{ Jenis Kelamin } & Laki-laki & 17 & $53,13 \%$ \\
\hline \multirow[t]{2}{*}{2} & & Perempuan & 15 & $46,88 \%$ \\
\hline & \multicolumn{2}{|c|}{ Total } & 32 & $100 \%$ \\
\hline 1 & \multirow[t]{6}{*}{ Penyakit yang diderita } & Demam Typoid & 7 & $21,87 \%$ \\
\hline 2 & & Diare & 4 & $12,50 \%$ \\
\hline 3 & & Faringitis Akut & 3 & $9,37 \%$ \\
\hline 4 & & OBS Febris & 13 & $40,62 \%$ \\
\hline 5 & & ISPA & 2 & $6,25 \%$ \\
\hline \multirow[t]{2}{*}{6} & & Tonsilitis & 3 & $9,37 \%$ \\
\hline & \multicolumn{2}{|c|}{ Total } & 32 & $100 \%$ \\
\hline
\end{tabular}

Mayoritas umur responden ialah usia 6 tahun sebanyak 8 orang $(25 \%)$ dan minoritas umur responden ialah usia 4,2 tahun sebanyak 1 orang (3,12\%). Mayoritas responden berdasarkan jenis kelamin adalah anak lakilaki sebanyak 17 orang $(53,13 \%)$ dan minoritas adalah anak perempuan sebanyak 15 orang $(46,88 \%)$. Sedangkan Mayoritas penyakit yang diderita anak usia pra sekolah di Wilayah Puskesmas Basirih Baru adalah obs Febris yaitu sebanyak 13 orang (40,62\%) dan minoritas adalah penyakit ISPA sebanyak 2 orang $(6,25 \%)$.

\section{B. Analisa Univariat}

Analisa univariat adalah analisis yang dilakukan untuk menganalisis tiap variabel dari hasil penelitian. Dalam penelitian ini analisis univariat yang dilakukan meliputi variabel independen kompres tepid water sponge dan kompres bawang merah, sedangkan variabel dependennya penurunan suhu tubuh. 
Tabel 1.2 Efektifitas pemberian kompres tepid water sponge dan kompres bawang merah terhadap penurunan suhu tubuh pada amak demam

\begin{tabular}{ccccccc}
\hline Metode perlakuan & \multicolumn{2}{c}{ Pre test } & \multicolumn{2}{c}{ Post Test } & \multicolumn{2}{c}{ Perubahan } \\
\cline { 2 - 6 } & Mean & $\begin{array}{c}\text { Std. } \\
\text { Deviation }\end{array}$ & Mean & $\begin{array}{c}\text { Std. } \\
\text { Deviation }\end{array}$ & Mean & $\begin{array}{c}\text { Std. } \\
\text { Deviation }\end{array}$ \\
\hline $\begin{array}{c}\text { Kompres tepid water } \\
\text { sponge }\end{array}$ & $37,64^{\circ} \mathrm{C}$ & 0,2732 & $\begin{array}{c}36,65 \\
0\end{array}$ & 0,3141 & $0,99{ }^{\circ} \mathrm{C}$ & 0,4266 \\
$\begin{array}{c}\text { Kompres bawang } \\
\text { merah }\end{array}$ & $37,58^{\circ} \mathrm{C}$ & 0,2729 & $\begin{array}{c}37,15 \\
\mathrm{C}\end{array}$ & 0,4098 & $0,43{ }^{\circ} \mathrm{C}$ & 0,2822 \\
\hline
\end{tabular}

Suhu tubuh klien sebelum diberikan kompres tepid water sponge (pretest) rata-rata $37,64^{\circ} \mathrm{C}(0,2732)$ dan sesudah pemberian (post test) rata-rata $36,65^{\circ} \mathrm{C}(0,3141)$, sedangkan suhu tubuh klien sebelum diberikan kompres bawang merah (pre test) rata-rata $37,58^{\circ} \mathrm{C}(0,2729)$ dan sesudah pemberian (post test) rata-rata $37,15^{\circ} \mathrm{C}(0,4098)$. Adapun perubahan suhu tubuh klien yang dilakukan pemberian kompres tepid water sponge rata-rata $0,99^{\circ} \mathrm{C}(0,4266)$ dan kompres bawang merah rata-rata $00,43{ }^{\circ} \mathrm{C}(0,2822)$.

C. Analisa Bivariat

1) Gambaran Suhu Tubuh Kelompok Kompres Tepid Water Sponge sebelum dan Sesudah Pemberian Perlakuan.

Tabel 1.3 Suhu Tubuh Responden Sebelum dan Sesudah Dilakukan Perlakuan Kompres dengan Tepid Water Sponge

\begin{tabular}{|c|c|c|c|}
\hline Kode & Sebelum Perlakuan & Sesudah perlakuan & Selisih \\
\hline 1 & $37,9^{\circ} \mathrm{C}$ & $36,4^{\circ} \mathrm{C}$ & $1,5^{\circ} \mathrm{C}$ \\
\hline 2 & $37,7^{\circ} \mathrm{C}$ & $36,2{ }^{\circ} \mathrm{C}$ & $1,5^{\circ} \mathrm{C}$ \\
\hline 3 & $38^{\circ} \mathrm{C}$ & $36,9^{\circ} \mathrm{C}$ & $1,1^{\circ} \mathrm{C}$ \\
\hline 4 & $37,5^{\circ} \mathrm{C}$ & $36,3^{\circ} \mathrm{C}$ & $1,2^{\circ} \mathrm{C}$ \\
\hline 5 & $38^{\circ} \mathrm{C}$ & $36,5^{\circ} \mathrm{C}$ & $1,5^{\circ} \mathrm{C}$ \\
\hline 6 & $37,9^{\circ} \mathrm{C}$ & $37^{\circ} \mathrm{C}$ & $0,9^{\circ} \mathrm{C}$ \\
\hline 7 & $38^{\circ} \mathrm{C}$ & $36,9^{\circ} \mathrm{C}$ & $1,1^{\circ} \mathrm{C}$ \\
\hline 8 & $37,5^{\circ} \mathrm{C}$ & $37^{\circ} \mathrm{C}$ & $0,5^{\circ} \mathrm{C}$ \\
\hline 9 & $37,3{ }^{\circ} \mathrm{C}$ & $36,7^{\circ} \mathrm{C}$ & $0,6^{\circ} \mathrm{C}$ \\
\hline 10 & $37,7^{\circ} \mathrm{C}$ & $36,5^{\circ} \mathrm{C}$ & $1,2^{\circ} \mathrm{C}$ \\
\hline 11 & $37,3{ }^{\circ} \mathrm{C}$ & $36,2{ }^{\circ} \mathrm{C}$ & $1,1^{\circ} \mathrm{C}$ \\
\hline 12 & $37,3^{\circ} \mathrm{C}$ & $37,1^{\circ} \mathrm{C}$ & $0,2^{\circ} \mathrm{C}$ \\
\hline 13 & $37,9^{\circ} \mathrm{C}$ & $36,3{ }^{\circ} \mathrm{C}$ & $1,6^{\circ} \mathrm{C}$ \\
\hline 14 & $37,5^{\circ} \mathrm{C}$ & $37^{\circ} \mathrm{C}$ & $0,5^{\circ} \mathrm{C}$ \\
\hline 15 & $37,4{ }^{\circ} \mathrm{C}$ & $36,8^{\circ} \mathrm{C}$ & $0,6^{\circ} \mathrm{C}$ \\
\hline 16 & $37,4^{\circ} \mathrm{C}$ & $36,6^{\circ} \mathrm{C}$ & $0,8^{\circ} \mathrm{C}$ \\
\hline Mean & $37,64{ }^{\circ} \mathrm{C}$ & $36,65^{\circ} \mathrm{C}$ & $0,99^{\circ} \mathrm{C}$ \\
\hline
\end{tabular}

Tabel ini menyatakan bahwa mean/rata-rata sebelum perlakuan adalah $37,64{ }^{\circ} \mathrm{C}$ dan sesudah perlakuan adalah $36,65^{\circ} \mathrm{C}$ kepada 16 responden. Dari hasil sebelum dan sesudah perlakuan tersebut dinyatakan bahwa terdapat pengaruh dibuktikan dengan $\mathrm{p}$ value $0,000<0,05$. 
2) Gambaran suhu tubuh kelompok kompres bawang merah sebelum dan sesudah pemberian perlakuan.

Tabel 1.4 Suhu Tubuh Responden Sebelum Dan Sesudah Dilakukan Perlakuan Kompres Bawang Merah

\begin{tabular}{|c|c|c|c|}
\hline Kode & Sebelum Perlakuan & Sesudah perlakuan & Selisih \\
\hline 1 & $37,4^{\circ} \mathrm{C}$ & $37^{\circ} \mathrm{C}$ & $0,4^{\circ} \mathrm{C}$ \\
\hline 2 & $37,5^{\circ} \mathrm{C}$ & $36,9^{\circ} \mathrm{C}$ & $0,6^{\circ} \mathrm{C}$ \\
\hline 3 & $38^{\circ} \mathrm{C}$ & $37,4^{\circ} \mathrm{C}$ & $0,6^{\circ} \mathrm{C}$ \\
\hline 4 & $37,3^{\circ} \mathrm{C}$ & $37^{\circ} \mathrm{C}$ & $0,3^{\circ} \mathrm{C}$ \\
\hline 5 & $37,5^{\circ} \mathrm{C}$ & $37,2^{\circ} \mathrm{C}$ & $0,3^{\circ} \mathrm{C}$ \\
\hline 6 & $37,8^{\circ} \mathrm{C}$ & $37,4^{\circ} \mathrm{C}$ & $0,4^{\circ} \mathrm{C}$ \\
\hline 7 & $37,3^{\circ} \mathrm{C}$ & $37^{\circ} \mathrm{C}$ & $0,3^{\circ} \mathrm{C}$ \\
\hline 8 & $37,4^{\circ} \mathrm{C}$ & $37^{\circ} \mathrm{C}$ & $0,4^{\circ} \mathrm{C}$ \\
\hline 9 & $37,3^{\circ} \mathrm{C}$ & $37,1^{\circ} \mathrm{C}$ & $0,2^{\circ} \mathrm{C}$ \\
\hline 10 & $37,7^{\circ} \mathrm{C}$ & $37,5^{\circ} \mathrm{C}$ & $0,2^{\circ} \mathrm{C}$ \\
\hline 11 & $38^{\circ} \mathrm{C}$ & $37,6^{\circ} \mathrm{C}$ & $0,4^{\circ} \mathrm{C}$ \\
\hline 12 & $37,9^{\circ} \mathrm{C}$ & $37,5^{\circ} \mathrm{C}$ & $0,4^{\circ} \mathrm{C}$ \\
\hline 13 & $37,3^{\circ} \mathrm{C}$ & $35,9^{\circ} \mathrm{C}$ & $1,4^{\circ} \mathrm{C}$ \\
\hline 14 & $38^{\circ} \mathrm{C}$ & $37,6^{\circ} \mathrm{C}$ & $0,4^{\circ} \mathrm{C}$ \\
\hline 15 & $37,4^{\circ} \mathrm{C}$ & $37,1^{\circ} \mathrm{C}$ & $0,3^{\circ} \mathrm{C}$ \\
\hline 16 & $37,6^{\circ} \mathrm{C}$ & $37,3^{\circ} \mathrm{C}$ & $0,3^{\circ} \mathrm{C}$ \\
\hline Mean & $37,58^{\circ} \mathrm{C}$ & $37,15^{\circ} \mathrm{C}$ & $0,43^{\circ} \mathrm{C}$ \\
\hline \multicolumn{4}{|c|}{$P: 0,001<0,05$} \\
\hline
\end{tabular}

Tabel diatas menunjukkan bahwa mean/rata-rata sebelum perlakuan adalah $37,58{ }^{\circ} \mathrm{C}$ dan sesudah perlakuan adalah $37,15{ }^{\circ} \mathrm{C}$ kepada 16 responden . Dari hasil sebelum dan sesudah perlakuan tersebut dinyatakan bahwa terdapat pengaruh dibuktikan dengan $\mathrm{p}$ value $0,001<0,05$.

Hasil penelitian ini menunjukkan bahwa kompres tepid water sponge lebih efektif menurunkan suhu tubuh pada anak demam dengan nilai mean sesudah perlakuan $36,65^{\circ} \mathrm{C}$ dibandingkan kompres bawang merah dengan nilai mean sesudah perlakuan $37,15^{\circ} \mathrm{C}$. Dibuktikan dengan nilai $\mathrm{p}$ value sig. 0,000 dan sig. $0,001<0,05$ yang berarti terdapat perbedaan suhu tubuh antara perlakuan kompres Tepid water Sponge dengan kompres Bawang merah yang signifikan.

\section{Pembahasan}

Responden yang diteliti berjumlah 32 orang yang dibagi menjadi dua kelompok penelitian yaitu pemberian kompres tepid water sponge dan kompres bawang merah. Responden dalam penelitian ini adalah anak-anak yang ada disekitar wilayah Kerja puskesmas Basirih Baru Banjarmasin.

Mayoritas umur responden ialah usia 6 tahun sebanyak 8 orang $(25 \%)$. Kemampuan anak terhadap infeksi dengan timbulnya manifestasi klinis demam sangat tergantung pada umur. Semakin muda usia anak, semakin kecil kemampuan untuk merubah set-point dan memproduksi panas. Hal ini diperkuat Menurut laporan Survei Demografi dan Kesehatan Indonesia (SDKI, 2012) diketahui bahwa 31\% anak usia dibawah 5 tahun menderita demam, pada saat usia 6-23 bulan angka menunjukkan 37\% lebih rentan mengalami demam, dan tiga dari empat anak demam yang dibawa ke fasilitas kesehatan sebesar 74\%. Soetjiningsih (2013) menyatakan bahwa perkembangan anak usia prasekolah lebih sering berkumpul dengan teman dan lebih sering melakukan interaksi sosial seperti bermain yang membuat anak lebih rentan terkena penyakit. Hal ini sejalan dengan Penelitian widyanti, et all (2015) yang mengemukakan bahwa usia 6 tahun sering mengalami demam dikarenakan anak masih rentan terhadap infeksi. Pada usia 3-6 tahun antibodi dan imunitas tubuh anak masih lemah dibandingkan dengan orang dewasa, sehingga virus dan bakteri mudah masuk dan menimbulkan infeksi.

Mayoritas responden dalam penelitian ini adalah anak laki-laki sebanyak 17 orang $(53,13 \%)$. Soedarmo (2013) bahwa suhu tubuh laki-laki dipengaruhi kegiatan metabolisme tubuh, pada lakilaki lebih tinggi dari perempuan karena perempuan dipengaruhi oleh siklus menstruasi. Hal ini juga diperkuat menurut teori Guyton \& Hall (2013) yang menyatakan bahwa metabolisme, rasio lemak dan otot pada laki-laki lebih tinggi dibanding perempuan yang membuat laki-laki lebih baik dalam memproduksi panas dalam tubuh. Kania (2013) mengutarakan laki-laki merupakan kelompok yang paling beresiko mengalami masalah demam, hal ini dikarenakan anak laki-laki lebih aktif bermain dan beraktifitas. Hal ini sesuai dengan penelitian Noviyanti (2012) bahwa laki-laki lebih rentan terkena demam dikaitkan dengan aktivitas laki-laki yang lebih sering di luar rumah yang 
memungkinkan laki-laki beresiko lebih besar terinfeksi bakteri dibandingkan dengan perempuan. Mayoritas responden yang ditemui adalah obs febris yakni sebanyak 13 orang $(40,62 \%)$. Suhu tubuh adalah perbedaan antara jumlah panas yang di produksi oleh proses tubuh dan jumlah panas yang hilang ke lingkungan luar. Panas yang dihasilkan dikurangi panas yang hilang merupakan disebut dengan suhu tubuh (Potter \& Perry, 2010). Demam merupakan respon normal tubuh terhadap adanya infeksi. Infeksi adalah keadaan masuknya mikroorganisme kedalam tubuh, dapat berupa virus, bakteri, parasit, maupun jamur. Demam pada anak umumnya disebabkan oleh infeksi virus (Setiawati, 2009). Demam juga dapat disebabkan oleh paparan panas yang berlebihan (overhating), dehidrasi atau kekurangan cairan, alergi maupun dikarenakan gangguan sistem imun (Lubis, 2009). Saraswati., et all (2015) mengemukakan bahwa observasi febris merupakan demam yang belum terdiagnosa dan mengevaluasi suatu penyakit. Febris adalah responden yang keadaan suhu tubuhnya diatas normal akibat peningkatan pusat pengaturan suhu di hipotalamus. Arianti (2016) yang mengatakan bahwa salah satu factor utama terjadinya demam adalah lingkungan yang tidak bersih yang menjadi tempat berkembang biaknya bakteri maupun virus, dimana bakteri dan virus adalah penyebab terjadinya reaksi tubuh yaitu demam, dan juga karena perubahan cuaca yang sering terjadi di Kalimantan Selatan menyebabkan anak sensitif terhadap perubahan suhu lingkungan. Anak yang mengalami demam bisanya mengalami peningkatan suhu tubuh, selain itu biasanya anak yang mengalami demam menjadi lebih rewel dari biasanya.

Suhu tubuh responden sebelum dilakukan pemberian kompres tepid water sponge memiliki rata - rata suhu tubuh $37,64{ }^{\circ} \mathrm{C}$ dan setelah dilakukan pemberian kompres tepid water sponge rata-rata suhu tubuh responden $36,65{ }^{\circ} \mathrm{C}$. Adapun perubahan suhu tubuh responden yang dilakukan pemberian kompres tepid water sponge yaitu sebanyak $0,99{ }^{\circ} \mathrm{C}$. Pada prinsipnya pemberian tepid water sponge dapat menurunkan suhu tubuh melalui proses penguapan dan dapat memperlancar sirkulasi darah, sehingga darah akan mengalir dari organ dalam kepermukaan tubuh dengan membawa panas. Kulit memiliki banyak pembuluh darah, terutama tangan, kaki, dan telinga. Aliran darah melalui kulit dapat mencapai 30\% dari darah yang dipompakan jantung. Kemudian panas berpindah dari darah melalui dinding pembuluh darah kepermukaan kulit dan hilang kelingkungan sehingga terjadi penurunan suhu tubuh (Potter \& Perry, 2010). Menurut penelitian ini juga diperkuat oleh Alves (2008), hasil penelitian pemberian water tepid sponge dan antipiretik efektif untuk menurunkan suhu tubuh anak pada 30 menit awal, dan menunnjukkan tren level suhu yang lebih tinggi dibandingkan anak yang hanya diberi antipiretik saja. Hasil penelitian ini sejalan dengan penelitian yang dilakukan oleh Maling (2012) didapatkan hasil $\mathrm{p}$ value $=0,001$ yang artinya ada pengaruh kompres tepid sponge terhadap penurunan suhu tubuh pada pasien hipertermi. Hasil penelitian ini sejalan dengan hasil penelitian terkait dimana ada pengaruh pemberian tepid water sponge terhadap penurunan suhu tubuh pada anak yang mengalami demam.

Suhu tubuh responden sebelum dilakukan pemberian kompres bawang merah rata-rata $37,58^{\circ} \mathrm{C}$ dan setelah dilakukan pemberian kompres bawang merah selama 20-30 menit rata-rata suhu tubuh $37,15{ }^{0} \mathrm{C}$, adapun perubahan suhu tubuh responden yang dilakukan pemberian kompres bawang merah sebanyak $0,43^{\circ} \mathrm{C}$. Bawang merah mengandung senyawa sulfur organic yaitu Allylcysteine sulfoxide (Alliin). Bawang merah yang digerus akan melepaskan enzim alliinase yang berfungsi sebagai katalisator untuk alliin yang akan bereaksi dengan senyawa lain misalnya kulit yang berfungsi menghancurkan bekuan darah (Utami, 2013). Kandungan minyak atsiri dalam bawang merah juga dapat melancarkan peredaran darah sehingga peredaran darah menjadi lancar. Kandungan lain dari bawang merah yang dapat menurunkan suhu tubuh adalah florogusin, sikloaliin, metialin, dan kaemferol (Tusilawati, 2012). Hal ini didukung dengan pendapat fatayati (2012) yang menyatakan bahwa bawang merah digunakan untuk efek yang mengeluarkan keringat dan sebagai pendingin suhu tubuh.

\section{Kesimpulan}

Rata-rata suhu tubuh sebelum dan sesudah dilakukan pemberian kompres tepid water sponge adalah $37,64{ }^{\circ} \mathrm{C}$ dan sesudah dilakukan pemberian adalah $36,65{ }^{\circ} \mathrm{C}$. Rata-rata suhu tubuh sebelum dan sesudah dilakukan pemberian plester kompres 37,58 ${ }^{0} \mathrm{C}$ dan sesudah dilakukan pemberian adalah 37,15 ${ }^{0} \mathrm{C}$. Ada perbedaan penurunan suhu tubuh pada pemberian kompres tepid water sponge $0,99{ }^{0} \mathrm{C}$ sedangkan pemberian kompres bawang merah penurunannya sebesar $0,43{ }^{0} \mathrm{C}$ dengan $\mathrm{p}$ value $=0,000$ pada kompres tepid water sponge dan $p=0,001$ pada kompres bawang merah $<0,05$. Jadi dapat disimpulkan bahwa pemberian kompres tepid water sponge lebih efektif untuk menurunkan suhu tubuh lebih dibandingkan dengan kompres bawang merah.

\section{Acknowledgment}

Ucapan terima kasih ditujukan kepada Ibnu Rifaldi selaku teman tim penelitian; Puskesmas Basirih Baru Banjarmasin yang telah berkenan menjadi tempat penelitian; Universitas Muhammadiyah Banjarmasin yang telah memberikan dukungan atas penelitian ini; Dinas Kesehatan Provinsi Kalimantan 
Selatan yang telah berkenan memberikan data- data terkait kepentingan penelitian ini; Dinas Kesehatan Kota Banjarmasin yang telah berkenan memberikan data- data terkait kepentingan penelitian ini, dan para responden dan orang tua responden yang telah berkenan menjadi bagian dalam penelitian ini

\section{Daftar Pustaka}

Alves, J. G. B., \& Almeida, C. D. C. M. 2012.Tepid Sponge Plus Dipyrone versus dipyrone alone for reducing body temperature in febrile children. Sao Paulo: Medical Journal. Diakses Pada Tanggal 12 Januari 2019 dari Http://www.scieolo.br

Dewi, A. K. (2016). Perbedaan Penurunan Suhu Tubuh Antara Pemberian Kompres Air Hangat Dengan Tepid Sponge Bath pada Anak Demam, Jurnal Keperawatan Muhammadiyah,1(1), 63-71. Diakses Pada Tanggal $30 \quad$ April 2019 dari http://journal.um-surabaya.ac.id

Dinkes Provinsi Kalimantan Selatan. (2018). Profil Kesehatan Provinsi Kalimantan Selatan. Banjarmasin: Dinas Kesehatan Provinsi Kalimantan Selatan.

Dinkes Kota Banjarmasin. (2018). Profil Kesehatan Kota Banjarmasin: Dinas Kesehatan Kota Banjarmasin.

Guyton, A. C., \& John E. Hall. (2013). Buku Ajar Fisiologi Kedokteran. Jakarta: EGC.

Hidayat, A.A. (2015). Metode penelitian keperawatan dan teknik analisis data. Jakarta: Salemba Medika.

Kania, N. (2013). Penatalaksanaan Demam Pada Anak. Bandung: Pustaka Unpad.

Maling, B. (2012). Pengaruh Kompres Tepid Sponge Hangat Terhadap Penurunan Suhu Tubuh Pada Anak Umur 1-10 Tahun Dengan Hipertermia (Studi Kasus Di RSUD Tugurejo Semarang). Karya Ilmiah, S.1 Keperawatan, Sekolah Tinggi Ilmu Kesehatan Telogorejo. Diakses Pada Tanggal $11 \quad$ Mei 2019 dari http://ejournal.stikestelogorejo.ac.id

Potter dan Perry. A. G. (2010). Fundamental Keperawatan Buku 3.Edisi 7.Jakarta : Salemba Medika.

Soedarmo, et all. 2013. Buku Ajar Ilmu Kesehatan Anak, Infeksi Dan Penyakit Tropis. Edisi I.Jakarta: Bagian Ilmu Kesehatan Anak FKUI, hlm. 89-97.

Suryono et al. (2012). Efektifitas Bawang Merah Terhadap Penurunan Suhu Tubuh Pada Anak Febris Usia 1 - 5 Tahun. Jurnal AKP, (6), 63-68. Diakses Pada Tanggal 9 Februari 2019 dari https://ojs.fdk.ac.id

Soetjiningsih. (2013). Tumbuh Kembang Anak. Jakarta: EGC.
Utami Prapti and Lina Mardiana. (2013). Umbi Ajaib Tumpas Penyakit. Jakarta: Penebar Swadaya, pp 54, 59, 65.

Wardiyah, A., Setiawati, dan Romayati, U. (2016). Perbandingan Efektifitas Pemberian Kompres Hangat dan Tepid Sponge terhadap Penurunan Suhu Tubuh Anak yang Mengalami Demam di Ruang Alamanda RSUD dr. H. Abdul Moeloek Provinsi Lampung Tahun 2015, Jurnal Kesehatan Holistik, 10(1): 36-44. Diakses Pada Tanggal 23 Maret 2019 dari http://ejurnalmalahayati.ac.id

Widyanti, Fatimah, dan Mardhiyah. (2015). Gambaran Pemeliharaan Suhu Tubuh Pada Anak Tifoid Melalui Metode Tepid Sponge Dan Kompres Dingin Dengan Kombinasi Antipiretik Di Ruang A.1 Perjan Rs Hasan Sadikin Bandung. Artikel Penelitian, 5(9), 75-85. Diakses Pada Tanggal 17 Januari 2019 dari http://perpus.stikep-ppnijabar.ac.id 